\title{
Need and Importance of work Life Balance in the Organization
}

\author{
Deepti Dubey (Research Scholar) \\ e-mail: deepty.varanasi@gmail.com
}

\author{
Dr. Geeta Rana (Associate Professor) \\ Swami Rama Himalayan University
}

\begin{abstract}
Work life balance (WLB) is viewed as a vital component comparable to employee performance. The study goal is to survey on WLB as it influence current work organization. The examination work tried to investigate broadly whether there is connection between work adaptability and nature of yield, manager/representative link and expanded efficiency, working condition and the pace of yield and in conclusion professional stability and employee retention. Consequently the examination demonstrated that work adaptability, business/representative relationship, working condition and professional stability have a constructive outcome on improved nature of yield, expanded efficiency, pace of yield between representatives, employee retention. The discoveries indicated that: employees respond contrarily when they encounter work life imbalance and that administration ought to receive WLB activities to upgrade worker execution. From the examination discoveries, it is presumed that WLB is of noteworthy pith to current work organizations.
\end{abstract}

Index Terms-Work life balance, managers, Representatives, Commitment, loyalty

\section{INTRODUCTION}

$\mathrm{I}$ $\mathrm{N}$ PRESENT scenario, there is an expansion in ideas of the weights that work has on family and on the employees life. This has incited investigation verging on WLB. In an condition of elevated degree of serious loads originating generally from works to bring greatness administration, the profundity on employees are monstrous. This is so in light of the fact that the inquiry of contention or border between people's personal lives and work related pressure is basic to comprehension how organizational can use on their presentation and profitability levels just as persuading staff for worker responsibility (Deery, 2008; Cannon, 1998; Aluko, 2009)

Numerous specialists have commonly concurred on the significant function of WLB as it is connected with an person's mental prosperity and in general feeling of concordance in life, which is a pointer of balance between the workplace job and the family (Clark, 2000)

Ongoing research shows that the two workers and associations profit by effectively work and family life balance (Greenhaus \& Powell, 2016; Hammer et al., 2015). WLB upgrades their prosperity and family fulfillment
(Grzywacz, 2000). In working areas, the nonattendance of WLB creates lackluster showing and more non-appearance of representatives (Frone et al., 1997), however, work and family life balance is related with expanded occupation fulfillment and authoritative responsibility (Cegarra-Leiva et al., 2012; Wayne et al., 2004). As it were, employees" WLB encounters develop their job related commitment, which is identified with organizational execution advancement (Carlson et al., 2006).

\section{REVIEW OF LITERATURE}

Merideth Ferguson et al (2012) comes across that WLB is suppose to be an intervening part in helping social backing's dedication to both work and family attainment.

Hua Jiang, (2012) demonstrated that, when employees immediate managers consider their junior as people with remarkable personality and require and entertain them the diversely however reasonably, workers look at them with elevated degree of confidence, trust, duty, contentment and command commonality, besides, employee while looking towards their dealing with reasonably by their organization create standard relationships with their organization. This examination likewise recognizes logical proper procedure and approaches utilize to prepare worklife choices as a huge predecessor encouraging high confidence, authority, attainment, and command commonality that workers see.

Goddard, et al., (2006) Environments with burden towards work, incorporatw with mentally prompted strain (work danger strain) have been linked with collapse, shrinking occupation fulfillment, and non appearance of authoritative authority.

Parikh and Gandhi (2014) reported towards the ongoing innovative changes attacked our home, rooms, and even communal capacities. Hereby examination recommendations were offered by creators to employees and associations. In one recommendations offered to associations expresses that associations could give "center hours" when a employee ought to be available and work around various beginning and finish times.

Gupta and Charu (2013) inspected the effect of WLB on work fulfillment of IT segment representatives.100 representatives were taken to gather information by receiving accommodation examining technique. A self-ar- 
ranged survey was directed. Chi-square outcome shows that WLB and burnout influences the activity fulfillment among representatives in IT division.

Panisoara and Serban (2013) have analyzed the effect of conjugal status on WLB. Information were gathered from 132 workers by receiving accommodation inspecting technique. Fluctuating non-business linked issues (by methods for the existence of a spouse, a minor or significant kid) while work being stable (by methods for the condition of being an utilized individual normal for all the four gatherings of members) may propose that the expansion of requests achieved by the need to expect family or childcare obligations isn't really trailed by a huge change in the degree of WLB experienced as unmarried worker

Kulkarni and Kulkarni (2012) have thought that fruitful representatives are perceiving that positive WLB results for workers from accomplishing work life parity to the fulfillment of testing work and profession advancement are crucial elements of an effective business technique.

Parida (2012) has referenced that these days the existence of workers of both the gender, is progressively devoured of family and other individual obligations and interests. Along these lines, with an end goal to hold employees, it is progressively significant for organization to perceive this WLB.

Xinyuan et.al (2011), When lodgings with family heartfelt work environments give acceptable assistance for work and family needs, workers without a doubt will have high business satisfaction. At the point when work and family generally sustain each other (i.e; family experiences improve the responsibilities to work, and unfortunate propensity versa), agents have a more solid way of life (Aryee et al; 2005).

Nancy R. Lockwood, (2003)discover growing degrees of pressure can rapidly incite low laborer resolve, helpless productivity, and lessening position satisfaction. Distinctive certifiable repercussions are misery, alcohols and prescription abuse, intimate and budgetary issues, constant dietary issues, and worker burnout.

Haddon and Hede, (2009) find that work encroach with home life more than home life interferes with work life, concerning time and imperativeness. Of course, home life enables individuals to come over of essentialness gone from working.

\section{RESEARCH PROBLEMS}

The work pressure, for those working in is raising over the most recent decades. Factors, for example, the advances in data innovation, and data load, the requirement for quick reaction, the significance appended to the nature of customer care and its suggestion for consistent accessibility and the movement of progress all interest our time and can be wellsprings of weight. If in current era, enough accentuation isn't set on employees balance among work and family than its impact can be seen on profitability which additionally influences the turnover in the association. Changing socio-economic are at the back of the transition to catch hold of work life programs. The decline in the conventional family, and increment in double profession couples, and a climb in the amount of single guardian suggest that agents are rearranging more obligations outside work.

WLB in the working environment has become a more noteworthy issue as nonappearance of it when all is said in done show negative results, for instance, high turnover, decrease in work duty, terrible nature of yield, low effectiveness, and nonattendance of occupation satisfaction. Study show that worker motivation and productivity is low when work/life exercises are missing, association obligation to work/life exercises is solidly agreed with employee motivation and proficiency.

WLB has given affiliations and homes stress due to its significance; it has consequences for various divisions of both the employees which over the long haul impact the organization. Inconsiderateness of WLB of employees have cost organizations, consequently there is the need to sort out it. Heather (2011) "You will never feel truly satisfied by work until you are satisfied by life".

\section{OBJectives OF THE STUDY}

Present examination focuses in depth examination of past exploration work accomplished on WLB. It gives a comprehension on the Organization and people, extension and status of WLB. The objectives are:

1. To analyze the indications of undesirable work life balance.

2. To distinguish what managers can accomplish to decrease work life balance in work place

3. To recommend steps to defeat work life balance

\section{Methodology}

The article includes information gathered from past writing accessible on WLB. The secondary sources of information incorporates information from distributed and unpublished sources including diaries, web and so on.

\section{A. The Signs of Unhealthy Work life Balance}

1. Weariness. At the point when work expanded timeframes reliably and disregard as far as possible between our work and home life, we end up encountering physical and mental exhaustion, we wind up experiencing physical and mental weariness. Subsequently, your capacity to think plainly and your eye-hand coordination endures. We are not so much gainful but rather more inclined to commit errors. Our mind is fluffy, our reflexes are more slow, and we are in danger of injury, obligation, and in any event, corrupting our expert notoriety dependent on moderate or incapable execution. 
2. Non attendance. At the point when we neglect to build up limits between our work and home life, we wind up missing significant family occasions. We additionally miss one of a kind minutes, commemorations, and birthday celebrations. Our nonattendance can truly harm our associations with friends and family and cause them to feel neglected.

3. No companionships. By investing the entirety of our energy zeroed in on our vocation, we don't devote whenever to sustaining and developing our friendships. Companions are a fundamental component of our emotionally supportive network. They shield us from getting segregated because of high measures of work and give us certain vitality and uphold. Having an emotionally supportive network is a vital aspect for having balance in our life, encountering fulfillments, and having individual fulfillment throughout everyday life. Be that as it may, companionships should be supported. Else, they don't keep going as long or their quality decreases.

4.Work load increment. The more hours we work at the workplace and the more reliably we do it, the more work we will get in remuneration. We will get greater obligation and more tasks. Presently, while this might be an incredible advance towards professional success and a pay increment, we need to ensure it isn't influencing different parts of our life. This is an elusive incline which can undoubtedly bring about a never finishing and expanding pattern of work, concerns, and weights. Having no work life balance or an undesirable measure of work life balance can bring about relentless measures of stress and health problems. It's easy to see how your career can affect your health.

\section{B. Changing Work Place for Wok Life Balance}

Having our working environment engaged with evaluating our work-life balance is a smart thought. The work environment ought to have the option to do the accompanying:

1.Caution the laborers of how long work hours could influence our prosperity.

2. Encourage the employees to be more open about their issues in work particularly with the hours. They should let the employees feel that they can support their privileges

3. Develop helpful arrangements that perceive the relationship of mental issue and business related stress. These standards should detail the obligations and functions of the workers to advance emotional well-being. The principles ought to likewise detail the systems on how the organization could help their staff who have emotional wellness issues.

4. Give improved trainings to managers to assist them with spotting helpless work-life parity and stress. The managers ought to likewise be very much prepared in growing better frameworks for ensuring their employees.
5. Making sure that the work can be overseen inside a time span; work with a prioritization plot; which means do the most significant undertakings first before proceeding onward to less significant work.

6. Energize loosening up schedules that could advance incredible psychological wellness like exercise.

7. Audit workplaces and recognize the components of strategy, practice or culture that could be harming to everybody's solid work-life balance.

8.Allow all the employees to go to help administrations and advising held at working hours just like they would go to a clinical arrangement.

9. Monitor and assess the approaches routinely against work pointers like nonattendance, infection and staff fulfillment.

\section{Recommendations to Overcome Stress and To have a Balanced Work Life}

1. Don't allow your employees to work for fixed timing every day but give them weekly hrs of working time to work and they should be allowed to manage the timing as per their convenience.

2. When conceivable, consolidate a work-from-home strategy. Offering this advantage even a couple of days every year can have any kind of effect.

3. Make day care accessible to staff nearby or consolidate an advantage which would give day care at a limited rate.

4. Build up an arrangement with a neighborhood drycleaning support or indeed having one on spot.

5. Offer an assessment planning administration advantage.

6. Offer unconditional present wrapping administrations during the special seasons and for unique events.

7. Consider giving high-performing workers family get-away bundles notwithstanding, or on the other hand instead of, money related rewards.

8. Offer attendant services to assist workers with adjusting the numerous tasks throughout everyday life.

9. Offer scheduling of flextime or offer a rotating schedule for the employees.

10. Offer occasional hours, where representatives can leave from the get-go Fridays during specific seasons.

11. Make yearly commemorations with the organization an extra taken care of time day to support representatives to commend their residency. This day away from work will likewise fill in as an update that their manager cares.

12. Encourage representatives to abstain from checking their work email and voice message after the workday what's more, on ends of the week, to isolate work from their own lives.

13. Allow representatives to take a more drawn out lunch, in the event that they come in ahead of schedule or work later, to make up the missed time. This choice will 
make it simpler for staff to plan arrangements or get things done on their break.

14. Hold virtual gatherings, so representatives don't need to be nearby to join in.

15. Encourage workers to take regular breaks to rehydrate for many occupied employees who neglect to take break of the day.

While the organization will most likely be unable to start these proposals, in any event, handling a couple of will help employees see your association's anxiety for genuine work/life balance in the working environment.

\section{CONCLUSION}

WLB is expanding in significance because of its advantages and its additional bit of leeway to employee also, organization performance. Organizations should put forth more attempts to actualize work-life well disposed strategies and make a workplace that suits its employee's government assistance and way of life to guarantee WLB, this is significant as employee with adjusted life's yield best outcomes. In this way work-life adjusts have gotten essential in organizations which think about progress as an choice. In view of the discoveries of the investigation, it very well may be reasoned that WLB holds a ton of well beings for organizations. It is a stage for upgrading employees execution and for possible accomplishment of hierarchical objectives. In the event If one has sorted out some way to designate the essential time for every part of life appropriately and not reflect the issues in a solitary bit of life, it suggests that he has had the alternative to achieve w WLB (Aycan et al., 2007)

\section{REFERENCES}

[1] Anjali Jindal, Shivani Agarwal, Pooja Garg, \& Renu Rastogi, (2013). "Gender Differences in Work-Life Balance: An Empirical Study", Journal of Management Research (ISSN-2319-7552), Vol. 1, No. 1, pp. 67-77.

[2] Aycan, Z., Eskin, M., \&Yavuz, S. (2007). Life balance. Istanbul: System Press.

[3] Blyton, P., \& Bacon, N. (2006). The effects of co-operating or conflicting over work restructuring: evidence from employees. The Sociological Review, Vol. 54(1), pp. 1-19.
[4] Carlson, D., Kacmar, K., Wayne, J., \& Grzywacz, J. (2006). Measuring the positive side of the work family interface. Development and validation of a work-family enrichment scale. Journal of vocational behavior, Vol.68(7), pp. 131-164.

[5] Cegarra-Leiva, D., Sánchez-Vidal, M., \& Gabriel CegarraNavarro, J. (2012). Understanding the linkbetween work life balance practices and organisational outcomes in SMEs. Personnel Review, Vol.41(3), pp. 359-379.

[6] Deery, M. (2008). Talent management, work-life balance and retention strategies. Int J Contemp Hospitality Mngt,Vol. 20(7), pp. 792-806.

[7] Edwards, J., \& Rothbard, N. (2000). Mechanisms linking work and family. Clarifying the relationship between work and family constructs.Academy of management Review., Vol.25(8), pp. 178199.

[8] Goddard, R., O'Brien, P., \& Goddard, M. (2006). Work environment predictors of beginning teacher burnout. British Educational Research Journal, Vol. 32(6), pp. 857-874.

[9] G.Panisoara,\& M. Serban,"Marital status and work-life balance." (2013) Procedia-Social and Behavioral Sciences, Vol. 78, pp.21-25.

[10] Grady, G., \& McCarthy, A. (2008). Work-life integration: experiences of mid-career professional working mothers. Journal Of Managerial Psych, Vol. 23(5), pp.5 99-622.

[11] Heather, S. (2011). Examining the relationship between work-life conflict and life satisfaction in executives. The role of problem focused techniques, Vol.8(3), pp. 4-10.

[12] Merideth Ferguson, Dawn Carlson, Suzanne Zivnuska and Dwayne Whitten (2012), "Support at Work and Home: The Path to Satisfaction through Balance", Journal of Vocational Behavior, Vol. 80, pp.299-307.

[13] M. S. Gupta,\& K. Charu (2013). "Analyzing work life balance and burnout as predictors of job satisfaction in IT industry of Gurgaon" A case study of IBM \& WIPRO in 2008-10. Journal of Business Management \& Social Sciences Research, Vol. 2(12), pp.1-7.

[14] Parikh, Rima and Gandhi, Hira 2014: "HR Interventions for Work Life Balance" International Journal for Research in Management and Pharmacy, Vol. 3(3), pp.20-26.

[15] R. Kulkarni, Sharad and Kulkarni, S. Sharwari,2012 "Work Life Balance and Stress Management: Two Sides of a Single Coin...!" Indian Journal of Commerce and Management Studies, Vol.1, pp.16-19.

[16] S. K. Parida, 2012"Measuring The Work Life Balance: An Interpersonal Study of the Employees In IT and ITES Sector." An International Referred Quarterly Business Research Journal,Vol. 1(1), pp. 123-134. 